\title{
Towards a Holistic Approach for Sustainable Partner Selection in the Electrics and Electronics Industry
}

\author{
David Wittstruck and Frank Teuteberg \\ Institute of Information Management and Corporate Governance, \\ Research Group in Accounting and Information Systems, \\ University of Osnabrueck, Katharinenstraße 1, 49069 Osnabrueck, Germany \\ Tel.: + 49541 969-4523, + $49541969-4961$ \\ \{david.wittstruck, frank.teuteberg\} @uni-osnabrueck.de
}

\begin{abstract}
In recent years numerous publications in the field of Supply Chain Management have dealt with partner selection methods. So far, research has failed to offer a holistic approach for the selection of recycling partners that accounts for financial, social and environmental factors. In view of this fact, our ;:that supports recycling partner selection in the electrics and electronics industry. Based on a systematic literature review we identify limitations of existing approaches and design an integrated Fuzzy-AHP-TOPSIS model. In addition, relevant criteria for sustainable partner selection are determined. The approach is illustrated by means of an exemplary case study.
\end{abstract}

Keywords: Sustainable Supply Chain Management, Partner Selection, Supplier Selection, Recycling, AHP, Fuzzy, TOPSIS, Multi Criteria Decision Making.

\section{Introduction}

In view of the constantly increasing global volume of electronic waste more and more companies are joining recycling networks based on multilateral business-to-business contracts to ensure secure waste disposal on a mid-term or long-term basis. These networks are facing a variety of challenges, as e.g. a multitude of (new) legal environmental demands and regulations (WEEE, RoHS Directive) as well as norms and standards (Energy Star Computer Program), extended reporting and publishing requirements (Sustainability Index, EMAS) and a shortage of natural resources. On top of this come the growing public interest in environmental protection (Green Logistics) and the employers' obligation to treat their staff responsibly (e.g. Ethical Trading Initiative (ETI) and Supplier Ethical Data Exchange (SEDEX)) - for example, employees must be sufficiently protected from the impact of hazardous substances (PVC, chlorine-containing PCBs). Therefore, in order to achieve a balance between social and environmental goals on the one hand and the need for long-term profitability on the other hand, the management of recycling networks needs to draw on adequate methods, technologies, information and communication systems. 
In response to the general call for a more sustainable economy (cf. Carter and Rogers, 2008; Seuring and Müller, 2007) Sustainable Supply Chain Management (SSCM) extends the traditional concept of Supply Chain Management by adding environmental and social/ethical aspects.

This article aims at developing an integrated multi-criteria decision model (MCDM) that supports recycling partner selection in the electrics and electronics industry and takes financial, environmental and social dimensions into account.

\section{Concept of Sustainable Supply Chain Management}

SSCM is based on the adoption and extension of supply chain management concepts. According to Harland, supply chain management can be defined as "the management of a network of interconnected businesses involved in the ultimate provision of product and service packages required by end customers" (Harland, 1996). SSCM can be extended by the concept of sustainability, which encompasses social, environmental and economic aspects (Carter and Rogers, 2008). Shrivastava takes a more ecological rather than sociological view at sustainability, which he defines as "the potential for reducing long-term risks associated with resource depletion, fluctuations in energy costs, product liabilities, and pollution and waste management" (Shrivastava, 2007). In contrast, Sikdar takes a "macro-viewpoint" at sustainability that includes social, environmental and economic aspects. He calls sustainability "a wise balance among economic development, environmental stewardship, and social equity" (Sikdar, 2003).

In order to achieve a balance between environmental, social and economic dimensions (idea of the "triple bottom line" developed by Elkington, 2004) we decided to follow the definition of SSCM formulated by Carter and Rogers who describe it as the strategic achievement and integration of an organization's social, environmental, and economic goals through the systemic coordination of key interorganizational business processes to improve the long-term economic performance of the individual company and its value network (Carter and Rogers, 2008).

Figure 1 illustrates the main components of SSCM, as well as the risks threatening it. The different dimensions of sustainability (environmental, economic and social performance of an organization) constitute three equally strong pillars that the building rests on, whereas risk and compliance management provide its foundation. The identification and mitigation of risks ensures long-term profitability. Laws, guidelines and standards serve as a basis for the implementation of SSCM throughout the supply chain.

Apart from that, SSCM includes values and ethics that need to be established in organizations. The concept also requires an efficient, flexible and "green" IT environment and the integration of the long-term goal of sustainable development into the corporate strategy. If these aspects are effectively combined, they can successfully protect the network against market, environmental and social threats and risks (cf. Figure 1). 


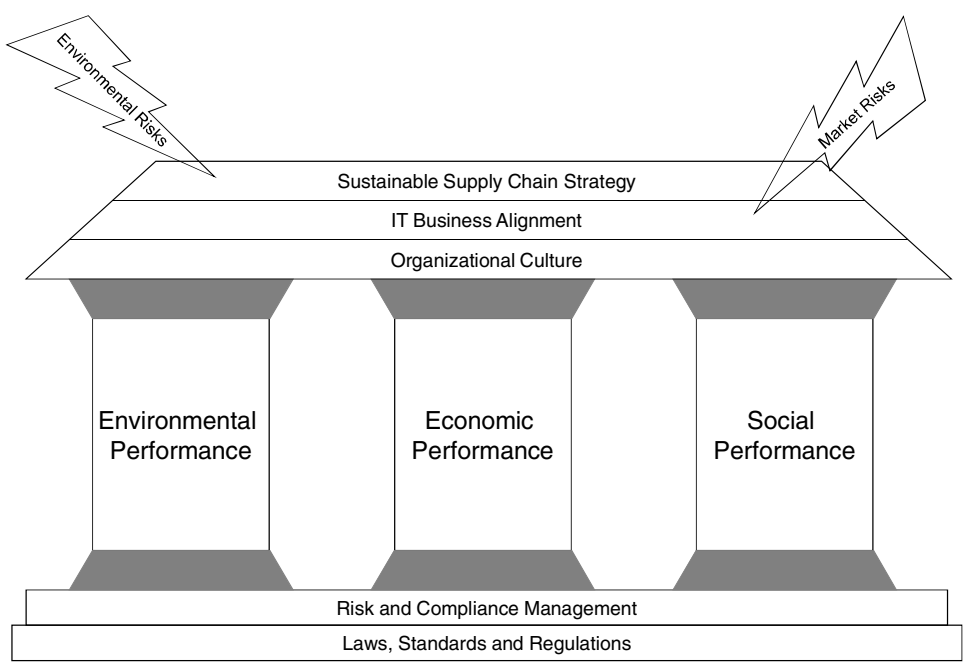

Fig. 1. House of SSCM (Wittstruck and Teuteberg 2010)

\section{Method}

The research method that this paper is based on can be characterized as design science research (Hevner et al., 2004) whereas the artefact developed in the following sections can be described as a holistic approach for sustainable partner selection in the electrics and electronics industry. The development of the model consists of the following phases:

\subsection{Literature Review}

A systematic literature review was conducted in order to determine the current state of research. The limitations of a systematic literature review lie in the paper selection process. However, we tried to minimize this risk by following a proven course of action for the creation of a literature review (Swanson, E.B., Ramiller, N.C. 1993, Webster, J. Watson, R., 2002). The restriction of the source material to high-quality articles leads to reliable results about the state of the art in SSCM research.

The search and the selection of the literature were carried out as follows: a systematic analysis of eleven high-quality journals was conducted. The oldest articles that were included date back to the year 1997. Table 1 shows the selected journals and how they have been evaluated in renowned international rankings. It becomes obvious from the table that only high-quality journals have been taken into account.

The following key words were used in order to achieve comprehensive search results: supply chain logistics, sustainability, green decision, multi objective, Analytical Hierarchy Process, Analytical Network Process, AHP, ANP, Fuzzy Logic, 
Table 1. Journal Selection (cf. Harzing 2009)

\begin{tabular}{|c|c|c|c|c|c|c|c|c|c|c|}
\hline & \begin{tabular}{|c|} 
Cranfield \\
University \\
School of \\
Manage \\
ment \\
2010 \\
\end{tabular} & \begin{tabular}{|c|} 
British \\
Association \\
of Business \\
Schools \\
(ABS) \\
Ranking \\
2010 \\
\end{tabular} & \begin{tabular}{|c|} 
Wirt- \\
schafts- \\
universitati \\
Wien \\
2008 \\
\end{tabular} & \begin{tabular}{|c|} 
VHB \\
Ranking \\
2008
\end{tabular} & $\begin{array}{c}\text { Centre } \\
\text { National } \\
\text { de la } \\
\text { Recherche } \\
\text { Scientifiqu } \\
\text { e 2008 }\end{array}$ & \begin{tabular}{|c|} 
Australian \\
Business \\
Deans Council \\
2008 \\
\end{tabular} & $\begin{array}{c}\text { Aston } \\
\text { University } \\
2008\end{array}$ & $\begin{array}{c}\text { University } \\
\text { of } \\
\text { Queenslan } \\
\text { d 2007 }\end{array}$ & \begin{tabular}{|c|} 
Erasmus \\
Research \\
Institute of \\
Manage \\
ment Journals \\
Listing 2006
\end{tabular} & $\begin{array}{l}\text { WKWI } \\
\text { 2008 }\end{array}$ \\
\hline \begin{tabular}{|l|} 
Information \\
Systems \\
Research \\
\end{tabular} & 4 & 4 & A+ & A+ & 1 & $\mathrm{~A}^{*}$ & 4 & 1 & STAR & $\mathrm{A}$ \\
\hline \begin{tabular}{|l|} 
International \\
Journal of \\
Innovation and \\
Sustainable \\
Development \\
\end{tabular} & N.R. & N.R. & N.R. & C & N.R. & $N . R$. & $N . R$. & N.R. & $N . R$. & N.R. \\
\hline \begin{tabular}{|l|} 
Int. Journal of \\
Logistics \\
Management \\
\end{tabular} & 3 & 2 & A & D & 3 & B & 1 & 3 & $\mathrm{~S}$ & $N . R$. \\
\hline \begin{tabular}{|l|} 
Int. J. of \\
Physical \\
Distribution \& \\
Logistics \\
Management \\
\end{tabular} & 3 & 2 & A & B & 4 & C & 1 & 3 & $\mathrm{~S}$ & N.R. \\
\hline \begin{tabular}{|l|} 
International \\
Journal of \\
Production \\
Research
\end{tabular} & 3 & 3 & A & B & 2 & A & 4 & 3 & $\mathrm{P}$ & N.R. \\
\hline \begin{tabular}{|l|} 
Journal of \\
Business \\
Logistics \\
\end{tabular} & 3 & 2 & N.R. & B & $N . R$. & B & 2 & 3 & $\mathrm{~S}$ & N.R. \\
\hline \begin{tabular}{|l|} 
Journal of \\
Cleaner \\
Production
\end{tabular} & $N . R$. & N.R. & $N . R$. & C & N.R. & N.R. & N.R. & N.R. & N.R. & N.R. \\
\hline \begin{tabular}{|l|} 
Logistics \\
Research
\end{tabular} & N.R. & N.R. & N.R. & N.R. & $N . R$. & $N . R$. & $N . R$. & $N . R$. & N.R. & N.R. \\
\hline \begin{tabular}{|l|} 
MIS Quarterly \\
\end{tabular} & 4 & 4 & $\mathrm{~A}+$ & A & 1 & $\mathrm{~A}^{*}$ & 4 & 1 & STAR & A \\
\hline \begin{tabular}{|l|}
$\begin{array}{l}\text { Naval Research } \\
\text { Logistics }\end{array}$ \\
\end{tabular} & $N . R$. & 3 & A & B & 3 & $\mathrm{~B}$ & N.R. & N.R. & $\mathrm{S}$ & $N . R$. \\
\hline \begin{tabular}{|l|} 
SCM: An \\
International \\
Journal \\
\end{tabular} & 3 & 3 & N.R. & C & 4 & A & 3 & 4 & $\mathrm{~S}$ & N.R. \\
\hline \begin{tabular}{|l|} 
Rank \\
Interpretation \\
$N . R .:$ Not ranked
\end{tabular} & 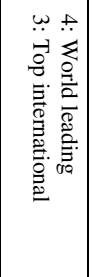 & 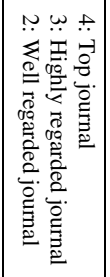 & 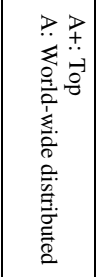 & 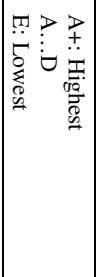 & 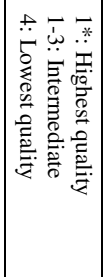 & 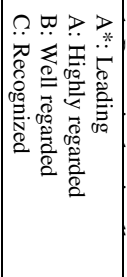 & 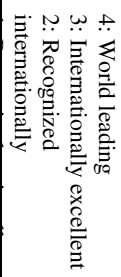 & 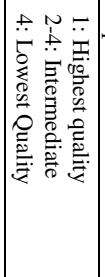 & 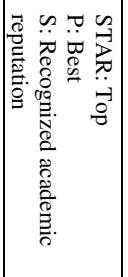 & $\stackrel{?}{\stackrel{7}{0}}$ \\
\hline
\end{tabular}


Data Envelopment Analysis, Promethee, TOPSIS, Technique for Order Preference by Similarity to Ideal Solution, Operational Competitiveness Rating, OCRA, Stochastic Frontier Analysis, SFA, Free Disposable Hull, FDH, Cross Efficiency Analysis, Recycling, and Recycling Networks. The inclusion of many synonyms and/or semantically very similar expressions led to more exhaustive search results. Each identified article was checked for its relevance to the topic by reading the respective abstract and introduction. Subsequently, according to the framework of literature analysis the main approaches, criteria, trends and validation methods of partner selection were analyzed. To improve the quality of the analyses, both authors of this paper were involved in reviewing and coding the analyzed articles. The inter-rater reliability was good (inter-rater percentage agreement: $>92 \%$ in all analyses).

\subsection{Partner Selection}

Because recycling companies can be both supplier (providing recycled materials for production) and customer (by purchasing used electronic devices) the term "partner selection" is preferred in this analysis to other known terms, e.g. 'supplier selection' or 'vendor 'selection' (Zarvić et al. 2010, Weber et al., 1991).

However, the selection of recycling partners focusing environmental, social and financial dimensions was not adequately tackled from the research community so far. In the section Development of a Partner Selection Method opportunities and limitations of these approaches regarding this topic are analyzed in order to develop an adequate holistic approach.

\subsection{Identification of Partner Selection Criteria}

First of all, existing partner selection criteria are identified on the basis of the systematic literature review. All criteria mentioned in the articles are extracted and tabulated. Table 3 also illustrates whether or not the criteria were validated in the research articles, and if yes, in what way.

\subsection{Criteria Validation and Weighting}

The criteria will be validated in the context of a survey among company representatives from recycling networks of the electrics and electronics industry. The experts will be asked whether the criteria mentioned in the literature seemed relevant to them. Also, they will be invited to name further criteria applied by their own or other companies. Subsequently, the participants will be asked to compare the criteria pairwise according to the AHP approach. A Fuzzy-AHP matrix will be generated on the basis of the participants' responses. Based on this matrix the criteria will be weighted by means of the software @ Risk, resulting in an average relative weighting of the relevant criteria. 


\subsection{Design of the Study}

The study is conducted by means of an online questionnaire and is carried out as follows:

Defining the Sample: Recycling networks of the German electrics and electronics industry will be selected to form the study sample. A special focus will be placed on products in the fields of entertainment electronics, telecommunication, computer hard-ware, medical technology or automotive IT. The reason for selecting these particular branches of production is that they cause particularly many ecological disturbances and, as a consequence, potential health problems. For example, some of the mentioned goods contain toxic substances and end up as e-waste on dumping grounds around the globe, e.g. in Asia or Africa, where they pollute the environment. Employees in production plants in China, Vietnam, Nigeria or India are not always sufficiently informed about the poisonous substances that they may be handling on a daily basis. Apart from these ecological considerations, the recycling of the above listed products (including disassembly, processing, separation, sorting of parts etc.) is almost as laborious as their production and causes the companies comparatively high costs (Walton, S.V. et al., 1998). In view of these problem complexes it becomes clear that the electrics and electronics industry is of special interest for researchers on SSCM, since it constitutes the primary target group for SSCM solutions.

Pre-Test: In February 2011, the questionnaire will be tested for comprehensibility in a pre-test with 10 participating business representatives.

Implementations: Between February and March 2011, experts will be invited to participate in the survey. These experts were mainly identified by searching the internet (search on "Xing" and "Linkedin"). A total of 3000 personal invitations to participate will be posted. We calculate a return rate of $3 \%$.

Analysis and Interpretation: An analysis phase will follow between March and April 2011. During this phase, the data will be consolidated evaluated by using AHPFuzzy-TOPSIS.

\subsection{Model Validation}

Implementation and Analysis: The individual steps from the Fuzzy AHP matrix and the weighted vectors to the final partner selection decision (by means of TOPSIS) are implemented in @ Risk in order to test to what extent the model can be integrated into available standard software. For the selection of a recycling partner by means of the TOPSIS method, the data of ten electronic waste recycling companies will be stored in @ Risk. The implementation of the model in @ Risk is a first step to verify the usefulness of the approach for business practice. All data relevant for the evaluation of the criteria shall be retrieved by analyzing the recycling companies' websites. 
Experiments: Experiments will be conducted in order to check whether the model influences the participants' decision making regarding sustainable partner selection.

\section{Results from the Literature}

At this point in time we have completed the third phase of our approach. The results gained on the basis of the systematic literature review are presented in the following section. In particular, the findings provide new insights regarding an adequate method for sustainable partner selection and relevant selection criteria.

\subsection{Development of a Partner Selection Method}

Important approaches for partner selection are summarized in Table 3. For our analysis, the following criteria were of particular interest:

- Approach: Which method was used?

- Focus on Sustainability: Does the article focus on financial, social and environmental issues?

- Industry Focus: What are the main results and topics?

- SCOR-Process: Which of the SCOR (Supply Chain Operations Reference Model) processes are considered?

- Purpose: What is the main objective?

- Findings: What are the findings?

- Major Limitations: What are major limitations?

Former research in the field of partner selection focused primarily on the "pre-stage" of the actual supply chain, that is, on direct suppliers (Ustun, O.; Demirtas, E.A., 2008); Kuoa, R. J.; Leeb, L. Y.; Huc, T.L., 2008); Kirytopoulos, K.; Leopoulos, V.; Mavrotas, G.; Voulgaridou, D., 2010). For the selection of recycling partners, however, this approach is insufficient because recycling companies can come into play both as a supplier and as a costumer the pre and post stage of the supply chain. For example, recycling companies can act as suppliers of recycled materials for the production of new goods or as buyers of electronic and other waste. Existing research works often focus on criteria like cost, time and quality (Zhu, Q.; Dou, Y.; Sarkis, J., 2010; Sarkis, J., 1998). Some authors also take environmental factors into account when discussing the issue of partner selection (Su, Y.; Jin, Z.; Yang, L., 2010; Sarkis, J., 1998; Sarmiento, R.; Thomas, A., 2010). However, a comprehensive view that integrates environmental, social and financial factors has been missing to date. Our study aims at filling this research gap.

Our Approach: Different methods for the weighting of criteria are suggested in the literature, the most popular ones being cost-utility analysis, quality function development and the AHP approach (Keeney, R.L.; Raiffa, H., 1993). Whereas quality function development is especially applied for the development of products 
Table 2. Partner Selection Approaches

\begin{tabular}{|c|c|c|c|c|c|c|c|}
\hline Approach & $\begin{array}{l}\text { Authors, } \\
\text { Year }\end{array}$ & $\begin{array}{l}\text { Focus on } \\
\text { Sustain } \\
\text { ability } \\
\end{array}$ & $\begin{array}{l}\text { Industry } \\
\text { Focus }\end{array}$ & $\begin{array}{l}\text { SCOR- } \\
\text { Process }\end{array}$ & Purpose & Findings & \begin{tabular}{|l} 
Major \\
limitations
\end{tabular} \\
\hline \multirow{4}{*}{ AHP } & $\begin{array}{l}\text { Sarmiento, } \\
\text { R.; Thomas, } \\
\text { A. (2010) }\end{array}$ & GreenSCM & No & Make & $\begin{array}{l}\text { - The purpose of this } \\
\text { paper is to discuss } \\
\text { research gaps and the } \\
\text { potential applications } \\
\text { of analytic hierarchy } \\
\text { process (AHP) in an } \\
\text { internal benchmarking } \\
\text { process used to identify } \\
\text { improvement areas } \\
\text { when firms attempt to } \\
\text { adopt green initiatives } \\
\text { with a supply chain } \\
\text { perspective. }\end{array}$ & $\begin{array}{l}\text {-The application of AHP to } \\
\text { study the various themes } \\
\text { mentioned above is not new. } \\
\text { Nevertheless, no previous } \\
\text { investigation has identified the } \\
\text { limitations in those studies. } \\
\text { Furthermore, previous paper } \\
\text { has not proposed a multitier } \\
\text { AHP approach to analyze the } \\
\text { problems firms taking part in a } \\
\text { supply chain might encounter } \\
\text { when implementing green } \\
\text { initiatives. }\end{array}$ & \multirow{4}{*}{$\begin{array}{l}\cdot \text { The } \\
\text { interrelatio } \\
\text { nship } \\
\text { among } \\
\text { criteria and } \\
\text { the } \\
\text { uncertainty } \\
\text { of human } \\
\text { decision } \\
\text { making are } \\
\text { not } \\
\text { considered. } \\
\text {-AHP } \\
\text { supports a } \\
\text { weighting } \\
\text { of } \\
\text { criteria/fact } \\
\text { ors but } \\
\text { gives only } \\
\text { few hints } \\
\text { how to find } \\
\text { the } \\
\text { supplier } \\
\text { which } \\
\text { meets these } \\
\text { criteria } \\
\text { best. } \\
\end{array}$} \\
\hline & $\begin{array}{l}\text { Liu, L.; } \\
\text { Berger, P.; } \\
\text { Zeng, A.; } \\
\text { Gerstenfeld, } \\
\text { A. (2008) }\end{array}$ & No & No & No & $\begin{array}{l}\text { - The purpose of this } \\
\text { paper is to show that } \\
\text { there is a wealth of } \\
\text { academic literature that } \\
\text { qualitatively examines } \\
\text { the outsourcing and } \\
\text { offshoring from a } \\
\text { go/no go perspective. } \\
\text { The paper examines } \\
\text { the complex "where to } \\
\text { outsource" question by } \\
\text { applying a quantitative } \\
\text { approach called } \\
\text { Analytic Hierarchy } \\
\text { Process (AHP). } \\
\end{array}$ & \begin{tabular}{|l|} 
The location selection \\
decision is a component of \\
the outsource supplier \\
selection decision. \\
-The AHP model effectively \\
manages the complexity of \\
the decision making process, \\
incorporating all decision \\
criteria harmoniously. \\
• A method such as AHP, \\
which is able to incorporate \\
both qualitative and \\
quantitative criteria into \\
evaluations, would streamline \\
the decision-making process. \\
-The AHP process allows \\
firms to look at a portfolio of \\
choices and determine which \\
firms are basically equal in \\
qualifications. \\
\end{tabular} & \\
\hline & $\begin{array}{l}\text { Gaudenzi, } \\
\text { B.; } \\
\text { Borghesi,A. } \\
(2006) \\
\end{array}$ & No & No & Plan & $\begin{array}{l}\text {-The aim of the } \\
\text { research is to provide a } \\
\text { method to evaluate } \\
\text { supply chain risks that } \\
\text { stand in the way of the } \\
\text { supply chain } \\
\text { objectives. }\end{array}$ & $\begin{array}{l}\cdot \text { The appreciation of the most } \\
\text { critical supply chain risks } \\
\text { comes from evaluations of } \\
\text { the impacts and a } \\
\text { consideration of the cause- } \\
\text { effect relationships. The } \\
\text { involvement of key managers } \\
\text { is essential. In the case study } \\
\text { the two most divergent } \\
\text { evaluations were from the } \\
\text { logistics manager and the } \\
\text { sales manager. } \\
\end{array}$ & \\
\hline & $\begin{array}{l}\text { Kahraman, } \\
\text { C.; Cebeci, } \\
\text { U.; Ulukan, } \\
\text { Z. (2003) }\end{array}$ & No & $\begin{array}{l}\text { White } \\
\text { good } \\
\text { manu- } \\
\text { facturer }\end{array}$ & Make & $\begin{array}{l}- \text { The aim of this paper } \\
\text { is to use fuzzy analytic } \\
\text { hierarchy process } \\
\text { (AHP) to select the } \\
\text { best supplier firm } \\
\text { providing the most } \\
\text { satisfaction for the } \\
\text { criteria determined. }\end{array}$ & $\begin{array}{l}\text {-The purchasing managers of } \\
\text { a white good manufacturer } \\
\text { established in Turkey were } \\
\text { interviewed and the most } \\
\text { important criteria taken into } \\
\text { account by the managers } \\
\text { while they were selecting } \\
\text { their supplier firms were } \\
\text { determined by a } \\
\text { questionnaire. The fuzzy } \\
\text { AHP was used to compare } \\
\text { these supplier firms. }\end{array}$ & \\
\hline
\end{tabular}


Table 2. (Continued)

\begin{tabular}{|c|c|c|c|c|c|c|c|}
\hline Approach & $\begin{array}{l}\text { Authors, } \\
\text { Year }\end{array}$ & $\begin{array}{l}\text { Focus on } \\
\text { Sustain } \\
\text { ability }\end{array}$ & $\begin{array}{l}\text { Industry } \\
\text { Focus } \\
\end{array}$ & \begin{tabular}{|l|} 
SCOR- \\
Process
\end{tabular} & Purpose & Findings & $\begin{array}{l}\text { Major } \\
\text { limitations }\end{array}$ \\
\hline \multirow{3}{*}{$\begin{array}{l}\text { Fuzzy and } \\
\text { AHP }\end{array}$} & $\begin{array}{l}\text { Bottani, } \\
\text { E.; Rizzi, } \\
\text { A. }(2005)\end{array}$ & No & \begin{tabular}{|l} 
E- \\
Procurement
\end{tabular} & Source & $\begin{array}{l}\text {-The paper addresses } \\
\text { the issues of how } \\
\text { supplier selection } \\
\text { criteria can be } \\
\text { usefully adopted in } \\
\text { real case applications } \\
\text { to ponder and rank } \\
\text { viable candidates. }\end{array}$ & $\begin{array}{l}\text {-The hierarchy covers } \\
\text { relevant issues related to e- } \\
\text { procurement deployment } \\
\text {-The framework seems } \\
\text { adequate, since advanced } \\
\text { MADM methods can be } \\
\text { applied easily in order to rank } \\
\text { potential candidates in terms } \\
\text { of the "electronic } \\
\text { transaction" criterion. }\end{array}$ & \multirow{3}{*}{\begin{tabular}{|l} 
\\
-The \\
interrelation \\
ships among \\
criteria are \\
not \\
considered. \\
• AHP \\
supports a \\
weighting of \\
criteria/facto \\
rs but gives \\
only few \\
hints how to \\
find the \\
supplier \\
which meets \\
these criteria \\
best.
\end{tabular}} \\
\hline & $\begin{array}{l}\text { Haq, } \\
\text { A.N,; } \\
\text { Kanaan, } \\
\text { G. (2006) }\end{array}$ & No & $\begin{array}{l}\text { Manu- } \\
\text { facturing } \\
\text { Company }\end{array}$ & Source & $\begin{array}{l}\text {-This paper presents } \\
\text { an integrated } \\
\text { approach for supplier } \\
\text { selection. } \\
\text { - The approach is } \\
\text { validated by a case } \\
\text { study performed in } \\
\text { an original } \\
\text { equipment } \\
\text { manufacturing } \\
\text { company located in } \\
\text { Southern India. } \\
\end{array}$ & $\begin{array}{l}\text {-A fuzzy analytical hierarchy } \\
\text { process (FAHP) and genetic } \\
\text { algorithms (GA) are } \\
\text { presented and validated. } \\
\text {-The approach supports } \\
\text { decision making in built-to- } \\
\text { order (BTO) supply chain } \\
\text { environments. }\end{array}$ & \\
\hline & $\begin{array}{l}\text { Lu, } \\
\text { L.Y.Y.; } \\
\text { Wu, C.H.; } \\
\text { Kuo, T.C. } \\
(2007)\end{array}$ & GreenSCM & No & Source & $\begin{array}{l}\cdot \text { Developing a } \\
\text { MODM-process for } \\
\text { GreenSCM to help } \\
\text { SC manager in } \\
\text { measuring and } \\
\text { evaluating suppliers' } \\
\text { performance based } \\
\text { on AHP decision- } \\
\text { making method. } \\
\text {-To reduce } \\
\text { subjective bias in } \\
\text { designing a } \\
\text { weighting system, a } \\
\text { fuzzy logic process } \\
\text { is used to modify the } \\
\text { AHP. }\end{array}$ & \begin{tabular}{|l} 
- This study presents a AHP \\
and Fuzzy approach to enable \\
managers to evaluate various \\
projects and establish an \\
environmentally benign \\
product design.
\end{tabular} & \\
\hline $\begin{array}{l}\text { AHP, } \\
\text { TOPSIS }\end{array}$ & $\begin{array}{l}\text { Perçin, S. } \\
(2009)\end{array}$ & No & No & Deliver & $\begin{array}{l}\text { - The purpose of this } \\
\text { paper is to provide a } \\
\text { good insight into the } \\
\text { use of a-two-phase } \\
\text { AHP and TOPSIS } \\
\text { approach that is a } \\
\text { multi-criteria } \\
\text { decision-making } \\
\text { methodology in the } \\
\text { evaluation of 3PL } \\
\text { providers. }\end{array}$ & $\begin{array}{l}\cdot \text { This model provides } \\
\text { decision makers with a } \\
\text { simple, flexible, and easy-to- } \\
\text { use approach to evaluate } \\
\text { potential 3PL providers } \\
\text { efficiently. Findings } \\
\text { demonstrate that the } \\
\text { proposed benchmarking } \\
\text { framework, with minor } \\
\text { modifications, can be useful } \\
\text { to all firms in their 3PL } \\
\text { provider selection decisions. }\end{array}$ & $\begin{array}{l}\cdot \text { The } \\
\text { interrelation } \\
\text { ship among } \\
\text { criteria and } \\
\text { the } \\
\text { uncertainty } \\
\text { of human } \\
\text { decision } \\
\text { making are } \\
\text { not } \\
\text { considered. }\end{array}$ \\
\hline
\end{tabular}


Table 2. (Continued)

\begin{tabular}{|c|c|c|c|c|c|c|c|}
\hline Approach & $\begin{array}{l}\text { Authors, } \\
\text { Year }\end{array}$ & \begin{tabular}{|l} 
Focus \\
on \\
Sustai- \\
nability
\end{tabular} & \begin{tabular}{|l} 
Industry \\
Focus \\
\end{tabular} & \begin{tabular}{|l|} 
SCOR- \\
Process
\end{tabular} & Purpose & Findings & $\begin{array}{l}\text { Major } \\
\text { limitations }\end{array}$ \\
\hline \multirow{4}{*}{ ANP } & $\begin{array}{l}\text { Bayazit, O. } \\
(2006)\end{array}$ & No & No & Source & $\begin{array}{l}\text {-The purpose of this } \\
\text { paper is to provide a } \\
\text { good insight into the } \\
\text { use of analytic } \\
\text { network process } \\
\text { (ANP) in evaluating } \\
\text { supplier selection } \\
\text { problems. }\end{array}$ & $\begin{array}{l}\text {-It is shown that ANP can be } \\
\text { used as a decision analysis } \\
\text { tool to solve multi-criteria } \\
\text { supplier selection problems } \\
\text { that contain } \\
\text { interdependencies. } \\
\text { • ANP is a complex } \\
\text { methodology and requires } \\
\text { more comparisons than the } \\
\text { traditional AHP and it } \\
\text { increases the effort. }\end{array}$ & \multirow{4}{*}{$\begin{array}{l}\text {-The } \\
\text { uncertainty } \\
\text { of human } \\
\text { being } \\
\text { decision } \\
\text { making is } \\
\text { not } \\
\text { considered. } \\
\text {-It is very } \\
\text { time- } \\
\text { consuming } \\
\text { to use this } \\
\text { complex } \\
\text { approach in } \\
\text { business } \\
\text { practice. }\end{array}$} \\
\hline & $\begin{array}{l}\text { Kirytopoulos } \\
\text {, K.; } \\
\text { Leopoulos, } \\
\text { V.; } \\
\text { Mavrotas, } \\
\text { G.; } \\
\text { Voulgaridou, } \\
\text { D. (2010) } \\
\end{array}$ & No & No & Source & $\begin{array}{l}- \text { The purpose of this } \\
\text { paper is to provide a } \\
\text { meta-model for } \\
\text { supplier evaluation } \\
\text { and order quantity } \\
\text { allocation, based on a } \\
\text { MCDM method, } \\
\text { namely the Analytic } \\
\text { Network Process } \\
\text { (ANP) and a } \\
\text { multiobjective } \\
\text { mathematical } \\
\text { programming method } \\
\text { (MOMP), the } \\
\text { AUGMECON. } \\
\end{array}$ & $\begin{array}{l}\text {-The proposed meta-model } \\
\text { constitutes an efficient } \\
\text { method that enables managers } \\
\text { to actively participate in the } \\
\text { decision making process and } \\
\text { exploit the "qualitative value" } \\
\text { of their suppliers, while } \\
\text { minimizing the costs and the } \\
\text { mean delivery times. In } \\
\text { addition, it is proved to be } \\
\text { suitable for the enterprise } \\
\text { clusters, as it adapts a } \\
\text { multiple sourcing strategy and } \\
\text { enhances the partnership } \\
\text { among the members. } \\
\end{array}$ & \\
\hline & $\begin{array}{l}\text { Zhu, Q.; } \\
\text { Dou, Y.; } \\
\text { Sarkis, } \\
\text { J.(2010) }\end{array}$ & $\begin{array}{l}\text { Environ } \\
\text { mental }\end{array}$ & No & Source & $\begin{array}{l}- \text { The purpose of this } \\
\text { paper is to present } \\
\text { the development of a } \\
\text { methodology to } \\
\text { evaluate suppliers } \\
\text { using portfolio } \\
\text { analysis based on the } \\
\text { analytical network } \\
\text { process (ANP) and } \\
\text { environmental } \\
\text { factors. }\end{array}$ & $\begin{array}{l}\text { - The technique is useful and } \\
\text { versatile. The paper clearly } \\
\text { discerns various } \\
\text { characteristics of the suppliers } \\
\text { and produced } \\
\text { recommendations on supplier } \\
\text { management for an exemplary } \\
\text { case scenario. }\end{array}$ & \\
\hline & \begin{tabular}{|l} 
Sarkis, J. \\
$(1998)$
\end{tabular} & $\begin{array}{l}\text { Environ } \\
\text { mental }\end{array}$ & No & No & $\begin{array}{l}- \text { This paper integrates } \\
\text { these elements and } \\
\text { their attributes into a } \\
\text { strategic assessment } \\
\text { and decision tool } \\
\text { using the systems } \\
\text { with feedback or } \\
\text { analytical network } \\
\text { process (ANP) } \\
\text { technique first } \\
\text { introduced by Saaty. }\end{array}$ & $\begin{array}{l}\text {-The ANP technique, which } \\
\text { has been sparingly } \\
\text { investigated by researchers or } \\
\text { applied by practitioners, is } \\
\text { useful for modeling dynamic } \\
\text { strategies systemic influences } \\
\text { on managerial decisions. }\end{array}$ & \\
\hline
\end{tabular}


Table 2. (Continued)

\begin{tabular}{|c|c|c|c|c|c|c|c|}
\hline Approach & $\begin{array}{l}\text { Authors, } \\
\text { Year }\end{array}$ & \begin{tabular}{|l} 
Focus \\
on \\
Sustain- \\
ability
\end{tabular} & $\begin{array}{l}\text { Industry } \\
\text { Focus }\end{array}$ & $\begin{array}{l}\text { SCOR- } \\
\text { Process }\end{array}$ & Purpose & Findings & $\begin{array}{l}\text { Major } \\
\text { limitations }\end{array}$ \\
\hline & $\begin{array}{l}\text { Ustun, O.; } \\
\text { Demirtas, } \\
\text { E.A. (2008) }\end{array}$ & No & \begin{tabular}{|l} 
Plastic \\
Molding \\
Firms \\
\end{tabular} & Source & $\begin{array}{l}\text {-The purpose of this } \\
\text { paper is to choose } \\
\text { the best suppliers. } \\
\text { •Defining the } \\
\text { optimum quantities } \\
\text { among selected } \\
\text { suppliers to } \\
\text { maximize the total } \\
\text { value of purchasing } \\
\text { (TVP), and to } \\
\text { minimize the total } \\
\text { cost and total defect } \\
\text { rate. }\end{array}$ & $\begin{array}{l}- \text { The quality of final solutions } \\
\text { obtained by } \epsilon \text {-constraint, } \\
\text { preemptive goal } \\
\text { programming (PGP) and } \\
\text { reservation level driven } \\
\text { Tchebycheff procedure } \\
\text { (RLTP) methods is compared } \\
\text { by using an additive utility } \\
\text { function. RLTP is better than } \\
\text { the others according. } \\
\text {-It is also possible to adapt } \\
\text { this multi-period MOMILP } \\
\text { model to multi-product case. } \\
\text { This integrated approach can } \\
\text { be improved to reflect } \\
\text { decision maker's preferences } \\
\text { with more accuracy. }\end{array}$ & \\
\hline $\begin{array}{l}\text { Fuzzy and } \\
\text { DEA; } \\
\text { Fuzzy and } \\
\text { AHP }\end{array}$ & $\begin{array}{l}\text { Kuoa, R. J.; } \\
\text { Leeb, L. Y.; } \\
\text { Huc, T.L. } \\
(2008)\end{array}$ & No & Automotive & Source & $\begin{array}{l}- \text { This study intends } \\
\text { to develop a novel } \\
\text { performance } \\
\text { evaluation method, } \\
\text { which integrates } \\
\text { both fuzzy analytical } \\
\text { hierarchy process } \\
\text { (AHP) method and } \\
\text { fuzzy data } \\
\text { envelopment } \\
\text { analysis (DEA) for } \\
\text { assisting } \\
\text { organizations to } \\
\text { make the supplier } \\
\text { selection decision. } \\
\end{array}$ & $\begin{array}{l}\text {-A Case study on an } \\
\text { internationally well-known } \\
\text { auto lighting OEM company } \\
\text { shows that the proposed } \\
\text { method is very suitable for } \\
\text { practical applications. }\end{array}$ & $\begin{array}{l}- \text { The } \\
\text { interrelation } \\
\text { ship among } \\
\text { criteria and } \\
\text { the } \\
\text { uncertainty } \\
\text { of human } \\
\text { decision } \\
\text { making are } \\
\text { not } \\
\text { considered. }\end{array}$ \\
\hline
\end{tabular}


and services, cost utility analysis has the disadvantage of not including the pairwise comparison of criteria. Instead, it is merely checked that the addition of all weighting factors does not result in a percentage higher than $100 \%$. Therefore, in this paper the AHP approach is used as a basis for the recording and weighting of the criteria. The Analytic Hierarchy Process makes it possible to create a hierarchical structure for a multicriterial decision problem and to aggregate it at the different levels, but on the other hand it neglects the uncertainty and imprecision of human thought. The Fuzzy Set Theory is applied to overcome this limitation, for fuzzy logic can be used to describe fuzzy quantities. Hence, a combination of both approaches seems promising. Subsequently, the TOPSIS method can be applied to find out which alternatives best fulfill the identified criteria; i.e. TOPSIS is used to compare and rank recycling partners and their criteria values. This happens by means of a relative efficiency analysis in which two virtual alternatives are defined: the overall best and the overall worst one. The characteristics of the potential partners need to be compared to these alternatives (Mahmoodzadeh et. al. 2010).

In summary, this article differs from similar works in several ways: an integrated Fuzzy-AHP-TOPSIS approach is taken, all dimensions of sustainability are considered for the selection of partners, the criteria are systematically derived and empirically validated, the focus is on recycling networks of the electrics and electronics industry and the model is evaluated on the basis of an exemplary implementation and experiments.

\subsection{Partner Selection Criteria}

In the context of our literature review we identified 35 articles in which partner selection criteria were analyzed. Table 4 provides an overview of these criteria. The number of proposed criteria per publication varies between 4 and 18, with an average number of 9 criteria. The criteria were mostly derived from literature and not always validated by experts from professional practice. It becomes immediately obvious that quality and delivery criteria are by far the most frequently proposed ones. Out of these, process quality (23 occurrences), delivery time (22 occurrences) and product quality (19 occurrences) (Webber et al., 1991; Bos-Brouwers, 2010; Choy, Lee, 2003) received the most mentions. Financial criteria like price (18 occurrences) and financial capability (12 occurrences) were also very frequently mentioned (Ordoobadi, 2009; Kwong et al., 2000; Chan et al., 2008). IT and risk criteria received a medium number of mentions (Petroni, A. et al., 2000; Sarkis, J. et al., 2002) whereas social and environmental criteria were only rarely referred to. The know-how and the working conditions of the employees were mentioned as social criteria. Repeatedly suggested environmental criteria were the use of environmental management systems (EMAS) and the type of product packaging (Sarkis, J. et al., 2002; Simpson, M.P. et al., 2002). 
Table 3. Review on Partner Selection Criteria

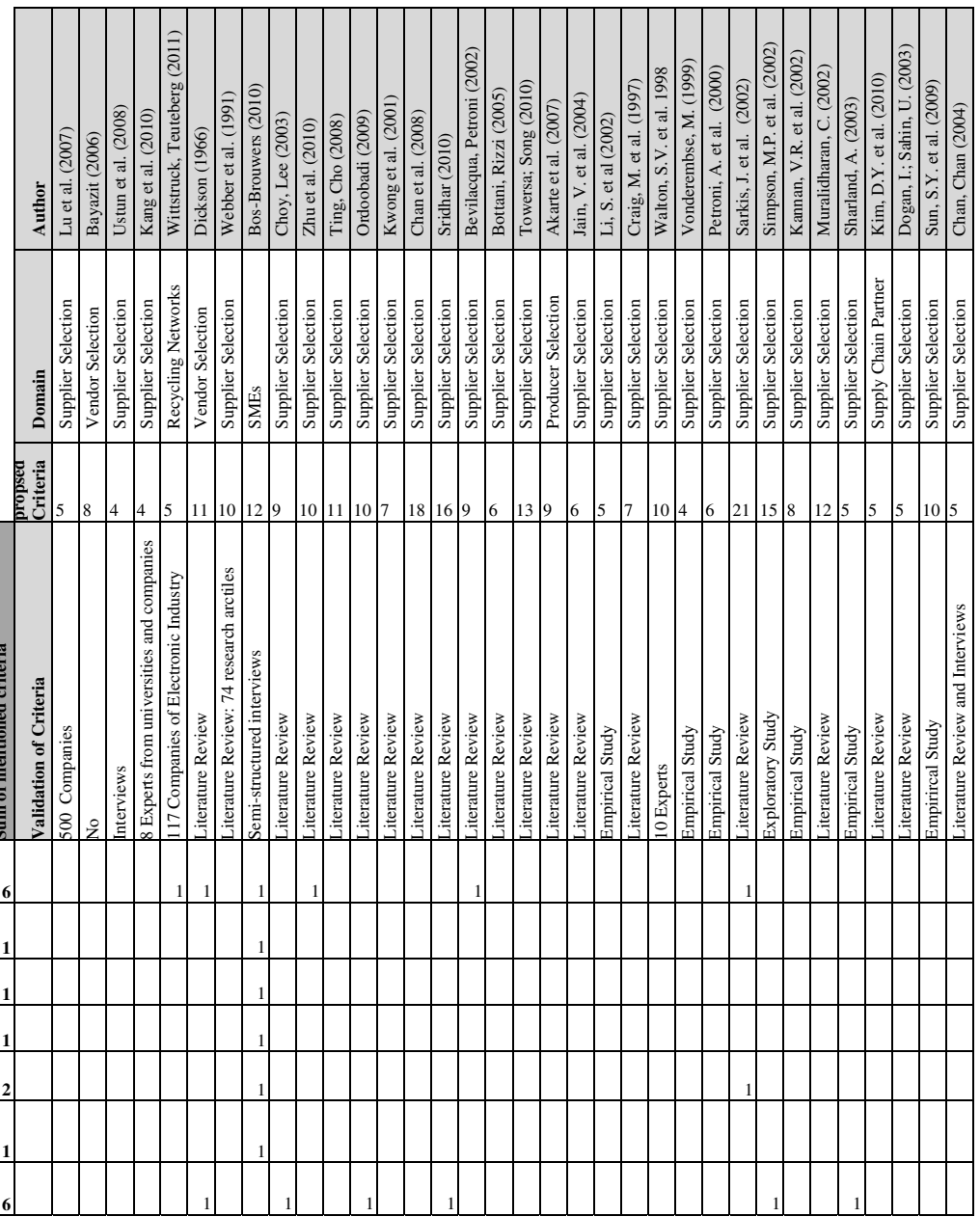


Table 3. (Continued)

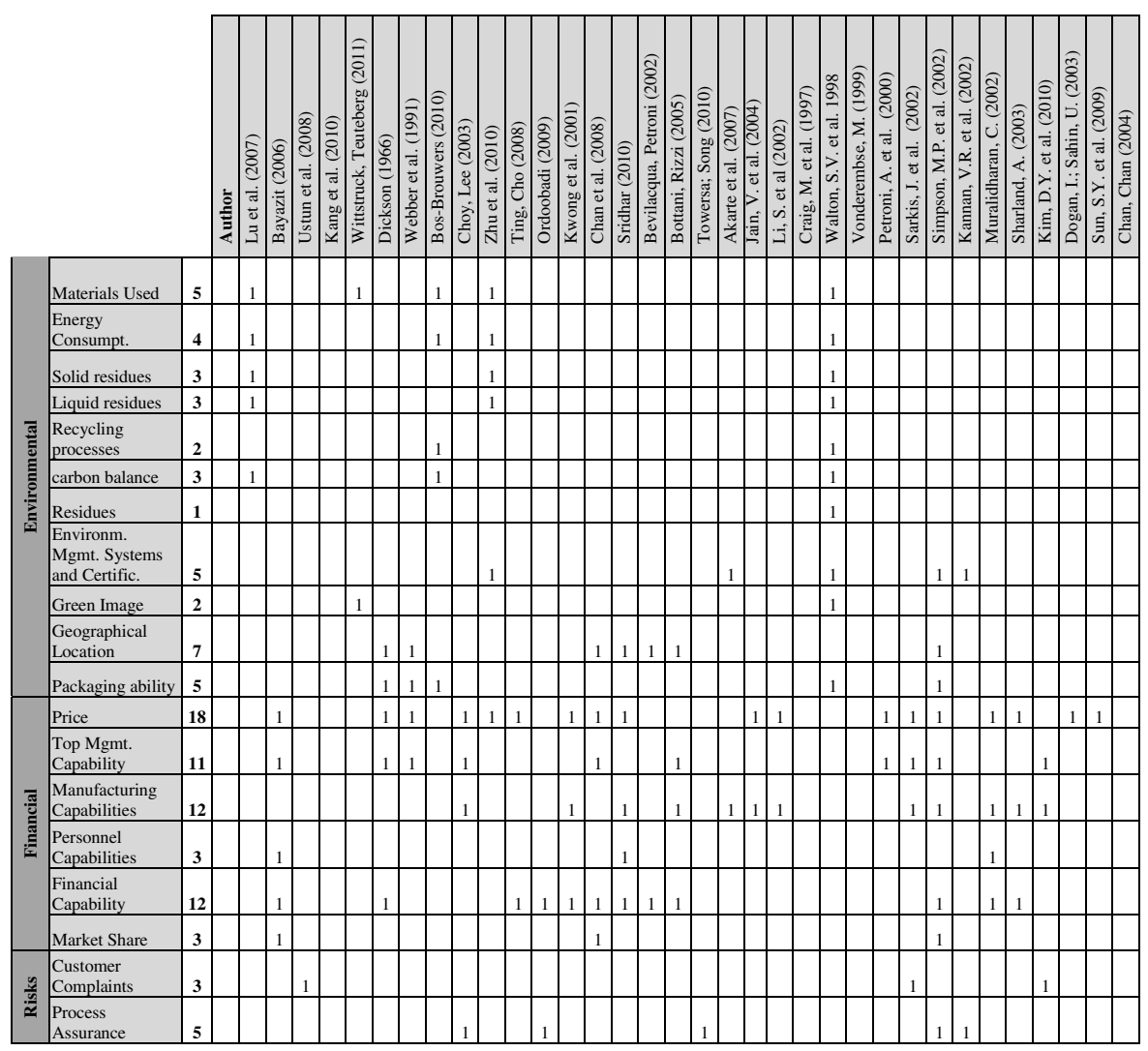


Table 3. (Continued)

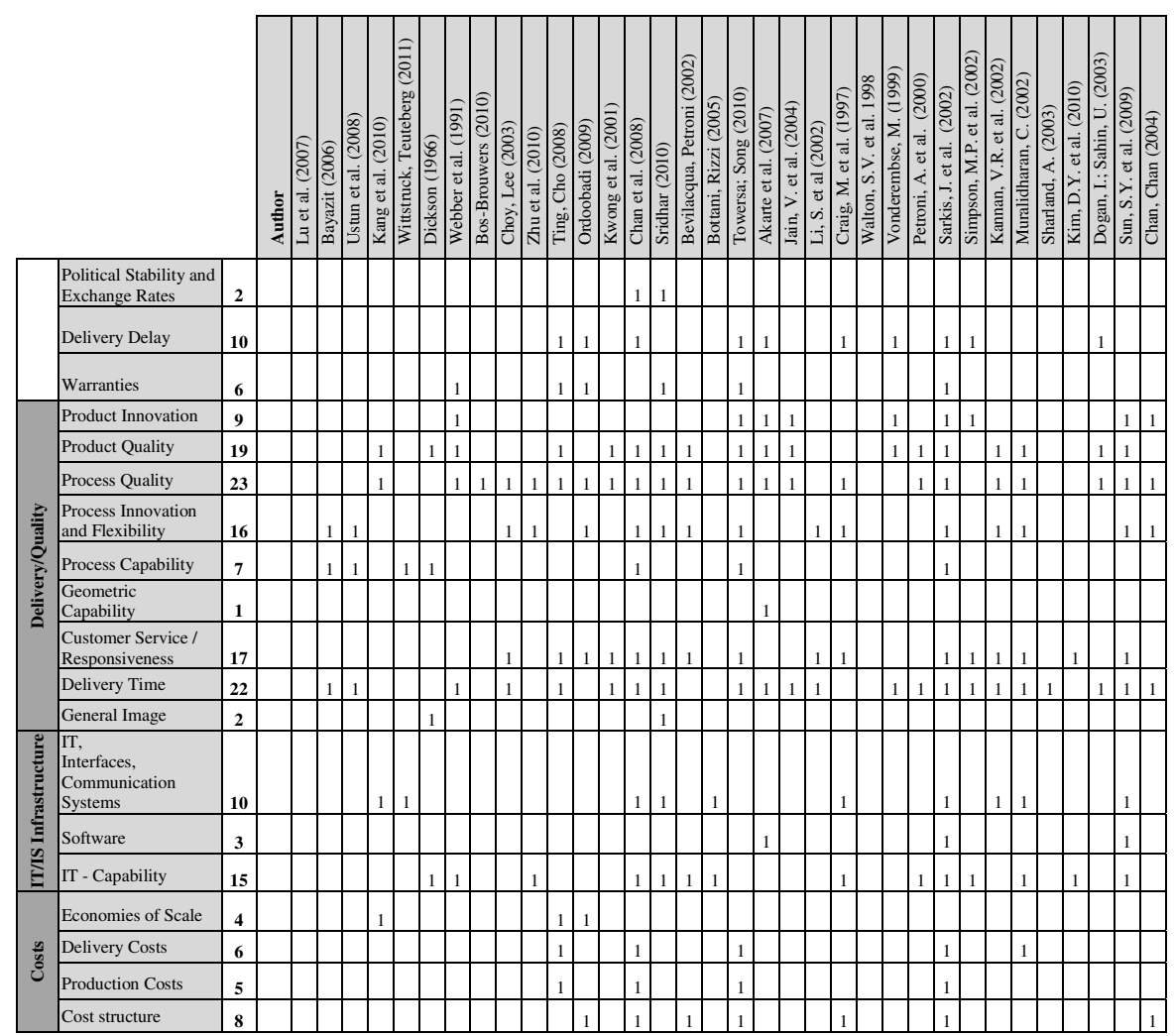


In view of all this, which criteria seem to be the most significant ones for the selection of recycling partners? According to the triple bottom line concept, the criteria should cover financial, environmental and social factors. Also, we want to account for the special characteristics of recycling companies. In accordance with the authors of the analyzed articles (as e. g. Ordoobadi, 2009; Kwong et al., 2000; Chan et al., 2008) we define price and financial capabilities as important criteria. In the context of this study, a recycling company's financial capability is regarded as a critical factor for its long-term capability to survive. In turn, the recycler's longterm survival is of high significance because electronic products often have a lifespan of several years, which means that cooperative relationships in the field of recycling must necessarily be long-term. Hence, we suggest the following selection critiera:

- Price

- Financial Capability

The main purpose of cooperating with a recycling company is to ensure the proper disposal of production materials and electronic waste. If required, the recycling company should be capable of recycling or disposing of large quantities of material and complex products (Dogan et al., 2003; Sun, et al., 2009). Hence, we suggest the following selection critiera:

- Recycling Capability

- Quality of Recycling Processes

Also, compliance with laws, guidelines and standards regarding the recycling and disposal of waste (WEEE, EuroStar etc.) constitutes a particular challenge for recycling companies because all these directives have a direct impact on their core business. Environmental Management Systems support the holistic management of environmental laws, guidelines and standards (Simpson et al., 2002; Kannan, et al., 2002). Thus, we suggest another selection criterion:

\section{- Effective Implementation of Environmental Management Systems}

Some of our electronic waste ends up at dumping grounds in Africa or in the Far East where health and safety measures are far less strict. If an international recycling company succeeds in communicating that it adheres to equally high safety standards for employees handling electronic waste at each of its locations, this can be a decisive competitive advantage (Bos-Brouwers, 2010). This correlation can be captured by means of the following criteria:

- Standardized Health and Safety Conditions

- Sustainable Image 
It must also be pointed out that recycling partners only receive their raw materials after they have been used by the customer. This temporal delay results in the need for especially careful coordination and planning way before the actual utilization of the recycling service. The producer and the recycler need to exchange particularly detailed information regarding the exact composition of the product to be recycled. Such an exchange of information enables recyclers to prepare for the specific recycling methods that new products may require. It is therefore very important to provide configurable IT interfaces that enable the exchange of information (Chan et al., 2008; Sridhar, 2010). As a result, we define another selection criterion:

\section{- Efficient IT-Interfaces}

Furthermore, recycling companies are often positioned at a pre-stage of the supply chain. They provide processed materials for further production and also act as consultants to producers regarding sustainable production methods and eco-friendly product composition (Ordoobadi, 2009; Sridhar, 2010; Bevilacqua, Petroni, 2002). Therefore, we add the following criterion to our catalogue:

- Know-how in Electronic Materials and Manufacturing Processes

All in all, we have suggested nine criteria, which correspond to the average number of criteria mentioned in related research articles. In business practice, these criteria could be used as a starting point for the solution of sustainable partner selection problems.

\section{An Exemplary Case Study}

At the current phase of our research project we are preparing an empirical study in order to validate our approach. However, we will illustrate our approach by means of an exemplary case study based on fictive data. We assume a decision maker who wants to evaluate three recycling partners by means of the Fuzzy-AHP-TOPSIS approach. The procedure can be summarized as follows (Saaty, 1980; Mahmoodzadeh et al., 2007):

1. Formulating hierarchy: The hierarchy is structured into different levels: the goal, the criteria and the alternatives level. The goal of our study is to select the most adequate partner. On the criteria level we model the selection criteria presented in the chapter on Partner Selection Criteria. Finally, on the alternatives level we model three alternative recycling companies. The hierarchy of our case study is presented in Figure 2. 


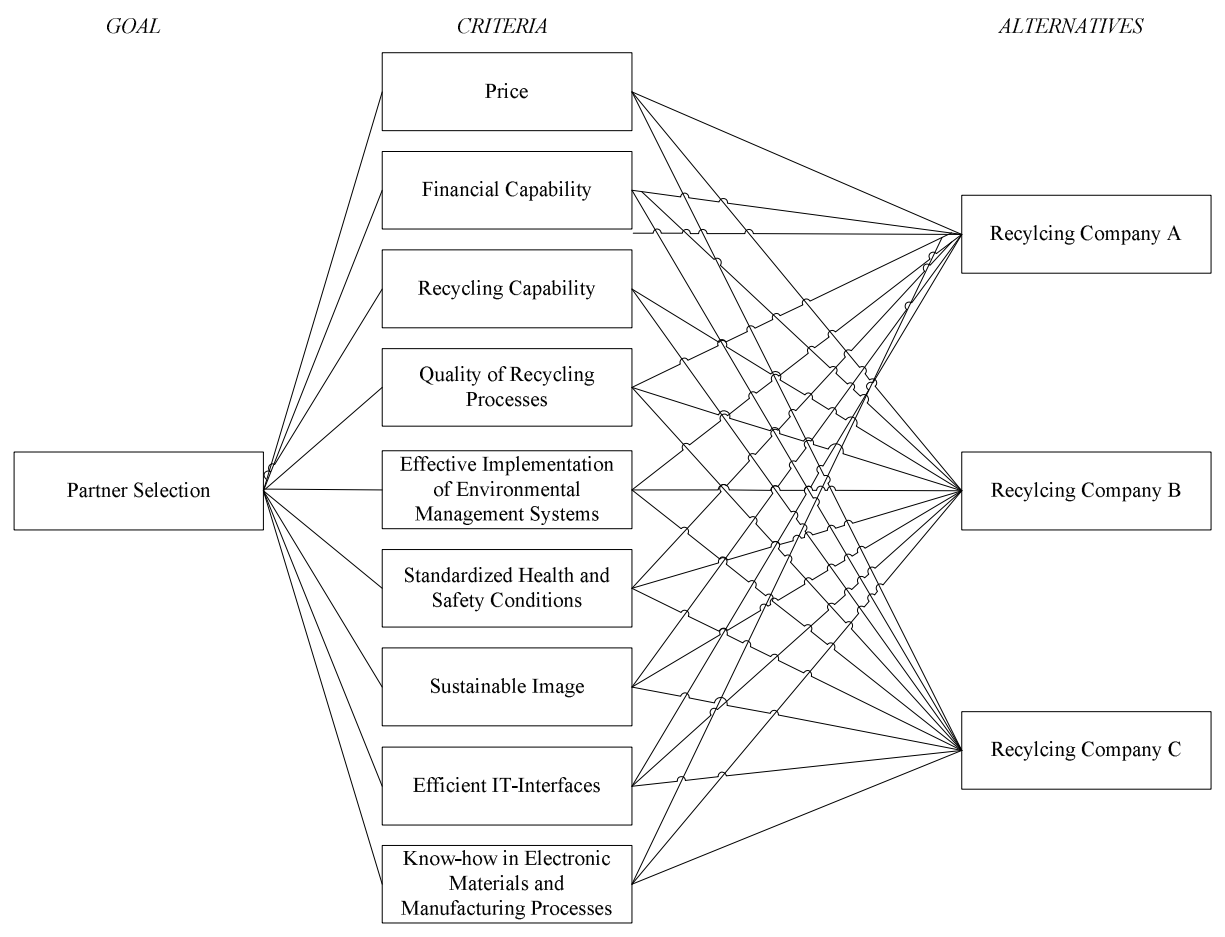

Fig. 2. Decision Hierarchy

2. Modeling Fuzzy Importance: A fuzzy set is a class of objects with a continuum of grades of membership. Such a set is characterized by a membership function, which assigns a grade of membership to each object that ranges between zero and one (Mahmoodzadeh et al., 2007). A triangular fuzzy number obtains three parameters that characterize the smallest possible value, the most promising value and the largest possible value. Table 4 provides an overview of the linguistic scale and the triangular fuzzy numbers assumed in this case study.

Table 4. Linguistic Scale

\begin{tabular}{|l|c|}
\hline \multicolumn{1}{|c|}{ Linguistic Scale } & $\begin{array}{c}\text { Triangular } \\
\text { Fuzzy Number }\end{array}$ \\
\hline Absolutely more important & $(5 / 2,3,7 / 2)$ \\
\hline Very strongly more important & $(2,5 / 2,3)$ \\
\hline Strongly more important & $(3 / 2,2,5 / 2)$ \\
\hline Weakly more important & $(1,3 / 2,2)$ \\
\hline Equally important & $(1 / 2,1,3 / 2)$ \\
\hline Just equal & $(1,1,1)$ \\
\hline
\end{tabular}


Figure 3 shows a Triangular Fuzzy Function $\mu(\mathrm{p})$. For instance, the linguistic scale "strongly more important" is determined by $\mathrm{p} 1=3 / 2, \mathrm{p} 2=2$ and $\mathrm{p} 3=5 / 2$.

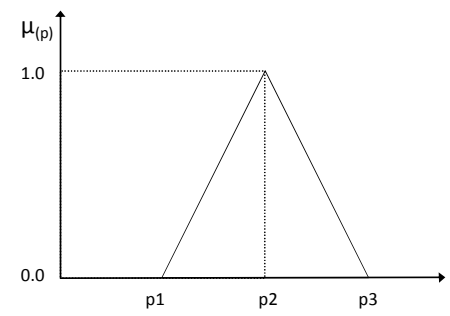

Fig. 3. Triangular Fuzzy Function

3. Creating an Evaluation Matrix: AHP uses pairwise comparisons to weight and rate the criteria. In our example the decision maker compares nine criteria with each other. Table 6 shows the exemplary evaluation matrix.

Table 5. Evaluation Matrix

\begin{tabular}{|c|c|c|c|c|c|c|c|c|c|}
\hline & Price & \begin{tabular}{|l} 
Fin. \\
Capa- \\
bility
\end{tabular} & $\begin{array}{l}\text { Recycling } \\
\text { Capability }\end{array}$ & \begin{tabular}{|l|} 
Quality of \\
Recycling \\
Processes
\end{tabular} & $\begin{array}{l}\text { Effective } \\
\text { Impl. } \\
\text { of EMIS }\end{array}$ & $\begin{array}{l}\text { Standar- } \\
\text { dized } \\
\text { H\&SC }\end{array}$ & $\begin{array}{l}\text { Sustainable } \\
\text { Image }\end{array}$ & \begin{tabular}{|l} 
Eff. IT \\
Interfaces
\end{tabular} & $\begin{array}{l}\text { EMMP } \\
\text { Know- } \\
\text { how }\end{array}$ \\
\hline Price & 1 & $(1,3 / 2,2)$ & $(1 / 2,2 / 5,1 / 3)$ & $(1,3 / 2,2)$ & $(1,3 / 2,2)$ & $(1 / 2,1,3 / 2)$ & $(1 / 2,1,3 / 2)$ & $(3 / 2,2,5 / 2)$ & $(1,3 / 2,2)$ \\
\hline $\begin{array}{l}\text { Financial } \\
\text { Capability }\end{array}$ & & 1 & $(1,2 / 3,1 / 2)$ & $(1 / 2,2 / 5,1 / 3)$ & $(1,3 / 2,2)$ & $(1,3 / 2,2)$ & $(2,5 / 2,3)$ & $(1 / 2,1,3 / 2)$ & $(1,3 / 2,2)$ \\
\hline $\begin{array}{l}\text { Recycling } \\
\text { Capability }\end{array}$ & & & 1 & $(1 / 2,2 / 5,1 / 3)$ & $(2,5 / 2,3)$ & $(1,3 / 2,2)$ & $(1,3 / 2,2)$ & $(2,5 / 2,3)$ & $(1,3 / 2,2)$ \\
\hline $\begin{array}{l}\text { Quality of } \\
\text { Recycling } \\
\text { Processes }\end{array}$ & & & & 1 & $(5 / 2,3,7 / 2)$ & $(2,5 / 2,3)$ & $(5 / 2,3,7 / 2)$ & $(1 / 2,1,3 / 2)$ & $(1 / 2,2 / 5,1 / 3)$ \\
\hline $\begin{array}{l}\text { Effective } \\
\text { Imple- } \\
\text { mentation } \\
\text { of EMS }\end{array}$ & & & & & 1 & $(1,3 / 2,2)$ & $(1 / 2,1,3 / 2)$ & $(1,3 / 2,2)$ & $(1 / 2,1,3 / 2)$ \\
\hline \begin{tabular}{|l|} 
Standar- \\
dized \\
H\&SC
\end{tabular} & & & & & & $(1,2 / 3,1 / 2)$ & $(5 / 2,3,7 / 2)$ & $(1,3 / 2,2)$ & $(3 / 2,2,5 / 2)$ \\
\hline \begin{tabular}{|l|} 
Sustainable \\
Image
\end{tabular} & & & & & & & 1 & $(2,5 / 2,3)$ & $(1 / 2,1,3 / 2)$ \\
\hline \begin{tabular}{|l} 
Efficient IT \\
Interfaces
\end{tabular} & & & & & & & & 1 & $(2,5 / 2,3)$ \\
\hline $\begin{array}{l}\text { Know-how } \\
\text { in EMMP }\end{array}$ & & & & & & & & & 1 \\
\hline
\end{tabular}


4. Calculating Normalized Weighting Factors: The normalized weighting factor reflects the relative importance of the partner selection criteria. It can be concluded from the following normalized weighting factor $\mathrm{W}$ that "price" $(0.21)$ is the most important selection criterion, followed by "quality of recycling processes" $(0.13)$ and "efficient IT interfaces" (0.12):

$\mathrm{W}=\{0.21,0.13,0.08,0.07,0.17,0.14,0.02,0.12,0.05\}$

5. Evaluating Alternatives: The TOPSIS approach is used to identify the optimal partner. To this end, after having calculated the normalized decision matrix, the weighted normalized decision matrix is calculated by multiplying the normalized decision matrix by its associated weights. Subsequently, the separation measures are calculated using the Euclidean distance (Mahmoodzadeh et al., 2007). Finally, the relative closeness to the ideal solution is calculated and a ranking of the three alternative companies is derived. As you can see from Table 6 Recycling Company $\mathrm{B}$ achieves the best score.

Table 6. Final Ranking of Recycling Partner

\begin{tabular}{|c|c|}
\hline Partner & Score \\
\hline Recycling Company A & 0.2156 \\
\hline Recycling Company B & 0.7321 \\
\hline Recycling Company C & 0.0103 \\
\hline
\end{tabular}

\section{Conclusion}

\subsection{Implications}

Due to the increasing number of electric devices being produced, the recycling of these materials will become more and more important. Thus, the selection of recycling partners with a view to environmental and social issues will become a significant topic for supply chain managers. The approach proposed in this paper considers the complexity of the supplier selection problem and includes financial, environmental and social dimensions. The model is intuitive and can be easily computerized. The results indicate that the Fuzzy-AHP-TOPSIS approach can be used as a decision making instrument for supply chain managers who need to select recycling partners. Both tangible and intangible factors can be incorporated into the model. In addition, assessment bias in pairwise comparison is reduced by combining AHP with fuzzy logic.

However, there are limitations to the approach. For instance, interrelationships among factors are not considered. If there are feedbacks and interdependencies among the factors, an unimportant factor may turn out to be far more important than even the most important one. The interdependencies that play a role in real-life partner selection problems are not captured in our study. Furthermore, the so-called Rank Reversal Problem has been pointed out by critics (Macharis et al., 2004). The term denotes that a ranking which is based on a comprehensive evaluation can be 
completely reversed by adding another alternative. For example, if criterion $\mathrm{A}$ is ranked higher than criterion $\mathrm{B}$, the addition of a third criterion $\mathrm{C}$ might change the ranking to $\mathrm{C}>\mathrm{B}>\mathrm{A}$. It is disputable whether there is an inherent logic to this phenomenon.

\subsection{Further Research}

Several research questions are still open at this stage: What do decision makers think of the suggested criteria? Will they consider them relevant? In what way does the holistic approach influence the decision making process?

These questions are will be part of our further research. As a next step we will verify the proposed criteria by interviewing experts from business practice. To this end an online questionnaire will be created. Subsequently, the approach will be implemented in @ Risk in order to provide a software tool for sustainable partner selection. The instrument will then be tested by means of experiments which will also serve to investigate to what degree the approach influences the participants' decisions regarding sustainable partner selection. All these steps are currently in preparation.

Acknowledgement. The authors are indebted to Ms Anja Grube and the anonymous reviewers for fruitful discussions and substantive comments relating to this paper.

This research is funded by the European Regional Development Fund (ERDF). The authors are pleased to acknowledge the support by ERDF and all involved project partners.

\section{References}

Akarte, M.M., Ravi, B.: Casting product-process-producer compatibility evaluation and improvement. International Journal of Production Research 45(21), 4917-4936 (2007)

Bayazit, O.: Use of analytic network process in vendor selection decisions; Benchmarking. An International Journal 13(5), 556-579 (2006)

Bevilacqua, M., Petroni, A.: From Traditional Purchasing to Supplier Management. A Fuzzy Logic-based Approach to Supplier Selection. International Journal of Logistics Research and Applications. A Leading Journal of Supply Chain Management 5(3), 235-255 (2002)

Bos-Brouwers, H.E.J.: Corporate sustainability and innovation in SMEs. evidence of themes and activities in practice. Business Strategy and the Environment 19(7), 417-435 (2010)

Bottani, E., Rizzi, A.: A fuzzy multi-attribute framework for supplier selection in an eprocurement environment. International Journal of Logistics Research and Applications. A Leading Journal of Supply Chain Management 8(3), 249-266 (2005)

Chan, F.T.S., Chan, H.K.: Development of the supplier selection model $\neg$ a case study in the advanced technology industry. Proceedings of the Institution of Mechanical Engineers - Part B - Engineering Manufacture 21(8), 1807-1824 (2004)

Chan, F.T.S., Kumar, N., Tiwari, M.K., Lau, H.C.W., Choy, K.L.: Global supplier selection. a fuzzy-AHP - approach. International Journal of Production Research 46(14), 3825-3857 (2008)

Carter, C., Rogers, D.: A framework of sustainable supply chain management: moving toward new theory. International Journal of Physical Distribution and Logistics Management 38(5), $56-68$ (2008) 
Choi, T.Y., Hartley, J.L.: An exploration of supplier selection practices across the supply chain. Journal of Operations Management 14(4), 333-343 (1996)

Chou, S., Shen, C., Chang, Y.: Vendor selection in a modified re-buy situation using a strategyaligned fuzzy approach. International Journal of Production Research 45(14), 3113-3133 (2007)

Choy, K., Lee, W.: A generic supplier management tool for outsourcing manufacturing. Supply Chain Management. An International Journal 8(2), 140-154 (2003)

Dibbern, J., Goles, T., Hirschheim, R., Jayatilaka, B.: Information systems outsourcing: a survey and analysis of the literature. The DATA BASE for Advances in Information Systems 35(4), 6-102 (2004)

Dickson, G.W.: An analysis of vendor selection systems and decisions. Journal of Purchasing 2(8), 5-17 (1966)

Dogan, I., Sahin, U.: Supplier selection using activity-based costing and fuzzy present-worth techniques. Logistics Information Management 16(6), 420-426 (2003)

Elkington, J.: Enter the triple bottom line. In The Triple Bottom Line: Does It All Add up? In: Henriques, A., Richardson, J. (eds.) Earthscan, London, pp. 1-16 (2004)

Gaudenzi, B., Borghesi, A.: Managing risks in the supply chain using the AHP method. International Journal of Logistics Management 17(1), 114-136 (2006)

Gustin, C.M., Daugherty, P.J., Ellinger, A.E.: Supplier Selection Decisions In Systems/Software Purchases. The Journal of Supply Chain Management 33(4), 41-46 (1997)

Harland, C.M.: Supply chain management: relationships, chains and networks. British Journal of Management 7(1), 63-80 (1996)

Harzing, A.W.: Journal quality list, 34th edn. (2009), http://www.harzing.com (accessed January 30, 2011)

Haq, A.N., Kannan, G.: Design of an integrated supplier selection and multi-echelon distribution inventory model in a built-to-order supply chain environment. International Journal of Production Research 44(10), 1963-1985 (2006)

Hevner, A.R., March, S.T., Park, J., Ram, S.: Design Science in Information Systems Research. MIS Quarterly 28(1), 75-105 (2004)

Jain, V., Tiwari, M., Chan, F.: Evaluation of the supplier performance using an evolutionary fuzzy-based approach. Journal of Manufacturing Technology Management 15(8), 735-744 (2004)

Jain, V., Wadhwa, S., Deshmukh, S.G.: Supplier selection using fuzzy association rules mining approach. International Journal of Production Research 45(6), 1323-1353 (2007)

Javalgi, R.G., Jain, H.K.: Integrating multiple criteria decision making models into the decision support system framework for marketing decisions. Naval Research Logistics 35(6), 575596 (1988)

Kahraman, C., Cebeci, U., Ulukan, Z.: Multi-criteria supplier selection using fuzzy AHP. Logistics Information Management 16(6), 382-394 (2003)

Kang, H.Y., Lee, A.H.I., Yang, C.Y.: A fuzzy ANP model for supplier selection as applied to IC packaging. Journal of Intelligent Manufacturing 21(1), 1-12 (2010)

Kannan, V.R., Tan, K.C.: Supplier Selection and Assessment. Their Impact on Business Performance. The Journal of Supply Chain Management 38(4), 11-21 (2002)

Keeney, R.L., Raiffa, H.: Decisions with Multiple Objectives; Preferences and Value Tradeoffs. Cambridge University Press, Cambridge (1993)

Kim, D., Kumar, V.K.A.U.: Performance assessment framework for supply chain partnership. Supply Chain Management. An International Journal 15(3), 187-195 (2010) 
Kirytopoulos, K., Leopoulos, V., Mavrotas, G., Voulgaridou, D.: Multiple sourcing strategies and order allocation. an ANP-AUGMECON meta-model. Supply Chain Management. An International Journal 15(4), 263-276 (2010)

Kuoa, R.J., Leeb, L.Y., Huc, T.-L.: Developing a supplier selection system through integrating fuzzy AHP and fuzzy DEA - a case study on an auto lighting System Company in Taiwan. Production Planning \& Control 21(3), 468-484 (2008)

Kwong, C.K., Ip, W., Chan, J.: Combining scoring method and fuzzy expert systems approach to supplier assessment - a case study. Integrated Manufacturing Systems 13(7), 512-519 (2002)

Lee, A.H.I.: A fuzzy AHP - evaluation model for buyer-supplier relationships with the consideration of benefits, opportunities, costs and risks. International Journal of Production Research 47(15), 4255-4280 (2009)

Li, S., Madhok, A., Plaschka, G., Verma, R.: Supplier-Switching Inertia and Competitive Asymmetry. A Demand-Side Perspective. Decision Sciences 37(4), 547-576 (2006)

Liu, L., Berger, P., Zeng, A., Gerstenfeld, A.: Applying the analytic hierarchy process to the offshore outsourcing location decision. Supply Chain Management. An International Journal 13(6), 435-449 (2008)

Lu, L.Y.Y., Wu, C.H., Kuo, T.C.: Environmental principles applicable to green supplier evaluation by using multi-objective decision analysis. International Journal of Production Research 45(18-19), 4317-4331 (2007)

Macharis, C., Springael, J., De Brucker, K., Verbeke, A.: PROMETHEE and AHP. The design of operational synergies in multi-criteria analysis. Strengthening PROMETHEE with ideas of AHP. European Journal of Operational Research 153(2), 307-317 (2004)

Muralidharan, C., Anantharaman, N., Deshmukh, S.: A Multi-Criteria Group Decisionmaking Model for Supplier Rating. The Journal of Supply Chain Management 38(4), 22-33 (2002)

Nassimbeni, G., Battain, F.: Evaluation of supplier contribution to product development. Fuzzy and neuro-fuzzy based approaches. International Journal of Production Research 41(13), 2933-2956 (2003)

Ordoobadi, S.: Application of Taguchi loss functions for supplier selection. Supply Chain Management. An International Journal 14(1), 22-30 (2009)

Pagell, M., Wu, Z.: Building an more complete Theory of Sustainable Supply Chain Management Using Case Studies of 10 Exemplars. Journal of Supply Chain Management 45(2), 37-56 (2009)

Park, D., Krishnan, H.A.: Understanding supplier selection practices. Differences between U.S. and Korean executives. Thunderbird International Business Review 43(2), 243-256 (2001)

Perçin, S.: Evaluation of third-party logistics 3PL providers by using a two-phase AHP and TOPSIS methodology. Benchmarking. An International Journal 16(5), 588-604 (2009)

Petroni, A., Braglia, M.: Vendor Selection Using Principal Component Analysis. The Journal of Supply Chain Management 36(2), 63-69 (2000)

Pochampally, K.K., Gupta, S.M.: Reverse Supply Chain Design. A Neural Network Approach. In: Wang, H.-F., Hua, T. (eds.) Web-Based Green Products Life Cycle Management Systems. Reverse Supply Chain Utilization, pp. 283-300 (2009)

Ramanathan, R.: Supplier selection problem. integrating DEA with the approaches of total cost of ownership and AHP. Supply Chain Management. An International Journal 12(4), 258261 (2007)

Saaty, T.L.: The analytic hierarchy process. McGraw-Hill, New York (1980)

Sarkis, J.: Evaluating environmentally conscious business practices. European Journal of Operational Research 107(1), 159-174 (1998) 
Sarkis, J., Talluri, S.: A Model for Strategic Supplier Selection. The Journal of Supply Chain Management 38(1), 18-28 (2002)

Sarmiento, R., Thomas, A.: Identifying improvement areas when implementing green initiatives using a multitier AHP approach. Benchmarking. An International Journal 17(3), 452-463 (2010)

Sharland, A., Eltantawy, R.A., Giunipero, L.C.: The Impact of Cycle Time on Supplier Selection and Subsequent Performance Outcomes. The Journal of Supply Chain Management 39(3), 4-12 (2003)

Shrivastava, S.K.: Green supply-chain management: a state-of-the-art literature review. International Journal of Management Reviews 9(1), 53-80 (2007)

Sikdar, S.K.: Sustainable development and sustainability metrics. AIChE Journal 49(8), 19281932 (2003)

Simpson, P.M., Siguaw, J.A., White, S.C.: Measuring the Performance of Suppliers. An Analysis of Evaluation Processes. The Journal of Supply Chain Management 38(1), 29-41 (2002)

Sridhar, C.N.V., Vijayakumar Reddy, K., Venugopal, R.V.: Investigations on Supplier Selection for e-Manufacturing. A Case study. International Journal of Business Insights and Transformation 3(2), 63-77 (2010)

Su, Y., Jin, Z., Yang, L.: System Dynamics Modeling for Strategic Management of Green Supply Chain. In: Hunter, M.G. (ed.) Strategic Information Systems. Concepts, Methodologies, Tools, and Applications, pp. 2617-2649 (2010)

Sun, S., Hsu, M., Hwang, W.: The impact of alignment between supply chain strategy and environmental uncertainty on SCM performance. Supply Chain Management. An International Journal 14(3), 201-212 (2009)

Swanson, E.B., Ramiller, N.C.: Information systems thematics: submissions to a new journal. Information Systems Research 4(4), 299-330 (1993)

Ting, S., Cho, D.I.: An integrated approach for supplier selection and purchasing decisions. Supply Chain Management. An International Journal 13(2), 116-127 (2008)

Torabi, S.A., Hassini, E.: Multi-site production planning integrating procurement and distribution plans in multi-echelon supply chains - an interactive fuzzy goal programming approach. International Journal of Production Research 47(19), 5475-5499 (2009)

Towers, N., Song, Y.: Assessing the future challenges in strategic sourcing commodity from China. a case-study analysis. Asia Pacific Business Review 16(4), 527-544 (2010)

Tsai, W., Hung, S.: A fuzzy goal programming approach for green supply chain optimisation under activity-based costing and performance evaluation with a value-chain structure. International Journal of Production Research 47(18), 4991-5017 (2009)

Ustun, O., Demirtas, E.A.: An integrated multi-objective decision-making process for multiperiod lot-sizing with supplier selection. Omega 36(4), 509-521 (2008)

Vonderembse, M.A., Tracey, M.: The Impact of Supplier Selection Criteria and Supplier Involvement on Manufacturing Performance. The Journal of Supply Chain Management 35(3), 33-39 (1999)

Walton, S.V., Handfield, R.B., Melnyk, S.A.: The Green Supply Chain. Integrating Suppliers into Environmental Management Processes. The Journal of Supply Chain Management 34(2), 2-11 (1998)

Wang, E.J., Chen, Y.C., Wang, W.S., Su, T.S.: Analysis of outsourcing cost-effectiveness using a linear programming model with fuzzy multiple goals. International Journal of Production Research 48(2), 501-523 (2010)

Weber, C.A., Current, J.R., Benton, W.C.: Vendor selection criteria and methods. European Journal of Operational Research 50(1), 2-18 (1991) 
Webster, J., Watson, R.: Analyzing the past to prepare for the future: writing a literature review. Management Information Systems Quarterly 26(2), 13-23 (2002)

Wittstruck, D., Teuteberg, F.: Sustainable Supply Chain Management in Recyclingnetzwerken der Elektro- und Elektroindustrie. In: Schumann, M., Breitner, M.H., et al. (eds.) Proceedings of Multikonferenz Wirtschaftsinformatik, Goettingen, pp. 1029-1043 (2010)

Zarvić, N., Seifert, M., Thoben, K.-D.: A task-resource dependency perspective on partner selection during the formation of networked business constellations. International Journal of Networking and Virtual Organisations 7(5), 399-414 (2010)

Zhu, Q., Dou, Y., Sarkis, J.: A portfolio-based analysis for green supplier management using the analytical network process. Supply Chain Management. An International Journal 15(4), 306-319 (2010) 